\title{
MARKETING STUDIES OF CONSUMPTION PREFERENCES AT DEVELOPING DIETARY PRODUCTS
}

\author{
Yana Biletska ${ }^{1}$ \\ ya.belecka@karazin.ua
}

Vitalina Babenko ${ }^{l}$

vitalinababenko@karazin.ua

Andrii Gusliev ${ }^{l}$

Guslev@karazin.ua

\author{
${ }^{1}$ International E-commerce and Hotel\&Restaurant Business Department \\ V.N. Karazin Kharkiv National University \\ 4 Svobody Sq., Kharkiv, 61022, Ukraine
}

\begin{abstract}
Results of marketing studies of consumption motivations and preferences at choosing bread for special dietary consumption are presented. It has been established, that $18 \%$ of questioned give advantage to bread with a decreased amount of carbohydrates; $17 \%$ of respondents consume bread without gluten; $13 \%$ give preference to products, including nutrients; $10 \%$ by iodine-containing bread; $7 \%$ and $6 \%$ of questioned give preference to bread with a content of soya and entersorbents. It has been established, that bread with a content of carotene and lecithin is not widely demanded among respondents as $3 \%$ for each one. Studies of $\%$ of preferences by flour types in the bread composition allowed to make conclusions that 19 and $17 \%$ of respondents give preference to corn and buckwheat flour due to a higher content of healthy substances, it is also an important advantage that these flour types don't contain cellulose complexes, present in the composition of wheat and barley flour, preferred by 14 and $11 \%$ of questioned, respectively. It has been established by the experimental way, that $20 \%$ of questioned persons feel a lack of bread with an increased content of protein at the market. 15, 12 and $10 \%$ of respondents want widening the assortment of bread with an increased content of macroelements, vitamins and microelements. 13 and $10 \%$ of questioned feel a lack at the market in such physiological-functional ingredients as polyunsaturated fatty acids and products of gluten-free flour. $8 \%$ of respondents want to see in the retail network products with a content of dietary fiber and antioxidants. $9 \%$ feel a lack of bread with a content of probiotics, $3 \%$ of oligosaccharides. Based on the obtained results, there have been determined consumption advantages: a modern consumer gives preference to products with the improved content, usual organoleptic parameters, long storage term, low price. He/she is guided by the following criteria at buying bread: food value, caloric value, prophylactic properties.

Keywords: consumption properties, dietary products, product of special destination, marketing studies.
\end{abstract}

DOI: 10.21303/2504-5571.2019.001009

\section{Introduction}

For today in our state the mean life duration of citizens is by $10-12$ years lower than in EU countries $[1,2]$, at that more than $50 \%$ of the population have not full-value, unbalanced nutrition that favors the development of alimentary and alimentary-dependent diseases [3, 4]. The Cabinet of Ministries of Ukraine accepted the target program "Health-2020: Ukrainian dimension", which concept is based on the development of high-quality products of mass consumption, with healthy, dietic effect, satisfying needs of consumers with certain diseases.

One of rational directions in the development of products for healthy nutrition is to develop products of mass consumption, including bread. Because of relatively low cost of initial raw materials, it is available for wide population layers and is able to compensate lacks of biologically active substances in the ration, to increase the organism resistance to unfavorable environmental factors, so to increase the life duration of the population $[5,6]$.

It is necessary to start creation of a high-quality product for healthy consumption from conducting marketing studies for revealing consumers' motivations and preferences. Studies of buyers' characteristics and revelation of their needs results in developing a product of healthy consumption that is competitive at the market that is satisfies consumers by its consumption properties and economic indices $[7,8]$. 
The development of technologies of products for special dietary consumption, widening and improvement of the assortment, increase of the food value is an urgent problem for today [9]. Questions about producing competitive goods that can be realized in European countries and correspond to conventional standards gain popularity in Ukraine [10]. According to the assessment of WHO and UNICEF specialists, more than one billion of people on the Earth have a risk of iodine-deficiency diseases development. Just this fact conditioned the inclusion of arrangements for preventing and controlling iodine-deficiency diseases in the number of priority international programs [11-13].

The Association of the European community of patients with the celiac disease accepted the program for 2020 year, which aim is to develop and widen the assortment of flour products, which gluten content doesn't exceed $20 \mathrm{mg} / \mathrm{g}$. [14, 15].

The production of goods for dietary (healthy consumption) must be near $35 \%$ of the total production of goods of this segment [16]. Taking into account the aforesaid and the fact that the production market of Ukraine is not sufficiently provided with products of dietary (healthy) consumption, the development of new products with given functional characteristics, based on consumers' wishes is extremely necessary. Bread relates to products of mass consumption and is one of most rational base products for fortification.

The aim of the research is to conduct marketing studies of consumers' preferences at developing products of dietary consumption.

\section{Materials and Methods}

The research method included the use of such management instrument as the polling method by a form $[17,18]$. A polling form consisted of information blocks, directed on solving the following questions: study of consumers' preferences at buying bread; determination of an importance degree of a series of consumption properties of given products; social-demographic characteristic of respondents; revelation of prospects of outputting new products with improved consumption/ healthy properties at the market. Consumers' requirements to the quality of a product were concretized (considered) step-by-step, starting from determining a necessity of outputting a product at the market and finishing by quality control methods $[19,20]$.

600 persons (210 practically healthy and 390 with certain diseases) took part in the polling. 150 persons - pupils of 7 ...11 classes and 60 persons - co-workers of the educational institution of the middle age. 109 persons - with iodine-deficiency statuses, 154 persons - with the celiac disease and 127 persons - with DM II type.

The respondents were distributed in the following way: depending on sex $-45 \%$ of male sex, $55 \%$ female sex. The respondents were distributed by age in the following way: $29 \%$ of respondents from 7 to 18 years, $18 \%$ of respondents from 18 to 25 years; $31 \%$ of respondents from 25 to 49 years; $22 \%$ of respondents of 50 years and more.

Depending on education level: with higher education $-50 \%$, unfinished secondary education $-29 \%$, secondary $-21 \%$. The sample included the following activity types: teachers $-8 \%$; workers - $9 \%$; officials - $10 \%$; retired - $22 \%$; students and schoolchildren - 30\%; entrepreneurs $15 \%$. A part of not working (unemployed, housewives) is $4 \%$. Another activity type was indicated by $2 \%$ of questioned.

\section{1. Experimental procedures}

The aim of the research is to conduct marketing studies of consumers' preferences at developing products of dietary consumption.

For attaining the set aim, the following tasks were solved:

- the study of $\%$ of bread consumption, depending on destination;

- the study of $\%$ of preferences by flour types in the bread composition;

- the determination of physiological-functional ingredients, which lack is felt most.

A question "Do you consume bakery products of special dietary destination?" was answered by $13 \%$ of respondents as don't consume, $87 \%$ of respondents (of different age categories and income level) buy them that characterizes this product as one of mass consumption. $13 \%$ of respon- 
dents consume bread every day, $34 \%$ of respondents $-2 \ldots 3$ times a week, $14 \%-1$ time a week, only $24 \%$ from time to time.

\section{2. The study of $\%$ of bread consumption, depending on destination}

At the experiment the bread was distributed in subgroups, depending on composition and destination as it is described in detail by SSU - P 4588:2006 "Bakery products of special dietary consumption" [17].

The study of $\%$ of bread consumption, depending on destination is presented on Fig. 1.

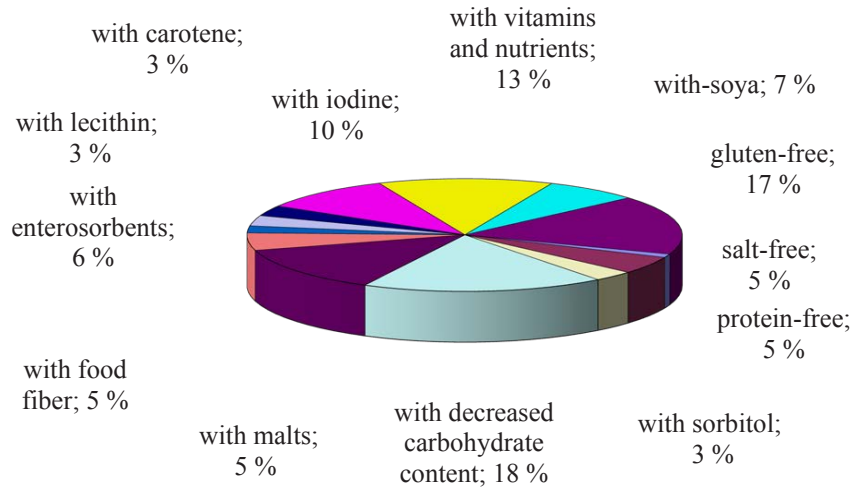

Fig. 1. The study of $\%$ of bread consumption, depending on destination

It has been established, that $18 \%$ of respondents give preference to products with a decreased content of carbohydrates; $17 \%$ of respondents consume bread without gluten; $13 \%$ give preference to products, containing vitamins and nutrients; $10 \%$ consume iodine-containing bread; $7 \%$ and $6 \%$ of interviewed give preference to products with a content of soya and enterosorbents. $5 \%$ consumers' preferences were obtained by salt-free, protein-free products and ones with malts and dietary fiber. It has been established, that bread with carotene, sorbitol and lecithin is not widely demanded by consumers (by $3 \%$ ).

\section{3. The study of \% of preferences by flour types, included in the bread composition}

The following stage of our studies was to investigate $\%$ of preferences by flour types in the bread composition. The results of the experiment are given on Fig. 2.

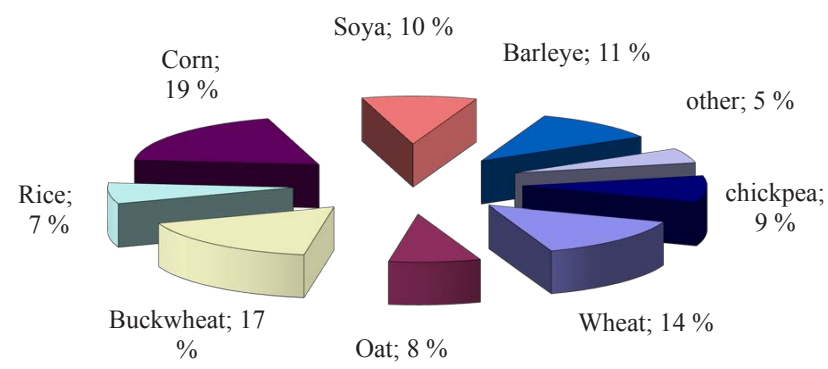

Fig. 2. The study of $\%$ of preferences by flour types in the bread composition

The conclusion was made that 19 and $17 \%$ of respondents give preference to corn and buckwheat flour, due to a higher content of healthy substances. Another important advantage became a fact that these flour types don't contain cellulose complexes, present in the composition of wheat and barley flour, preferred by 14 and $11 \%$ of interviewed, respectively. Soya and chickpea flour are preferred by 10 and $9 \%$ of interviewed. Rice flour is preferred by $7 \%$ of consumers and $5 \%$ of respondents prefer other flour types. 


\section{4. The determination of physiological-functional ingredients, which lack is felt most}

The following stage of our studies was to determine physiological-functional ingredients in the bread composition, which lack is felt most by a consumer. The research results are presented on Fig. 3.

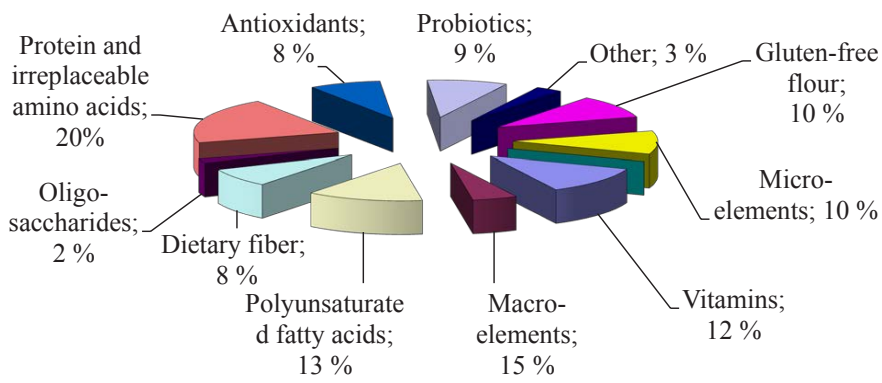

Fig. 3. Determination of physiological-functional ingredients in the bread composition, which lack is felt most

It has been experimentally established, that $20 \%$ among respondents feel a lack of bread with an increased content of protein and irreplaceable amino acids at the market. 15, 12 and $10 \%$ of respondents want widening the assortment of bread with the increased content of macroelements, vitamins and microelements. 13 and $10 \%$ of questioned feel a lack at the market in such physiological-functional ingredients as polyunsaturated fatty acids and products of gluten-free flour. $8 \%$ of respondents want to see in the retail network products with a content of dietary fiber and antioxidants. $9 \%$ feel a lack of bread with a content of probiotics, $3 \%$ of oligosaccharides.

\section{Results and Discussion}

According to SSU - P 4588:2006 "Bakery products of special dietary destination", such products are divided in two groups, depending on composition and destination: salt-free products for nutrition of people with kidney diseases; protein-free products - for nutrition of patients with protein metabolism disorders; sorbitol-containing products - for nutrition of patients with diabetes mellitus and also ones, who control own body mass; products with a decreased carbohydrate content; products with adding the malt extract - for nutrition of patients with hepatitis; products, enriched with dietary fiber - for improving the intestine motility; products with enterosorbents for removing toxic elements and radionuclides; products with lecithin; products with b-carotene for providing the deficiency of vitamin A, immunity improvement; products, enriched with iodine - for preventing iodine-deficiency statuses; products, enriched with vitamins, macro- and microelements - for preventing vitamin, macro- and microelement deficiency; products with soya - for enriching with vegetable protein and improving the amino acid composition of a product. Taking into account the fact that the celiac disease (unassimilability of gluten) becomes more and more often diagnosed in Ukraine, it is considered reasonable to include this parameter at conducting the experiment.

The generalization of the studies in part 2. 1 gives reasons to state that the rather essential percent of interviewed give preference to products with an increased content of carbohydrates and gluten-free flour. Products with iodine content (7\%), are priority by nutrients that is explained by geographic poverty of our territories in this microelement. Unessential percent of consumers (5\%) eat salt-free and protein-free bread (Fig. 1).

The conclusion was made that 19 and $17 \%$ of respondents give preference to corn and buckwheat flour due to a higher content of healthy substances, it is also an important advantage that these flour types don't contain cellulose complexes, present in the composition of wheat and barley flour, preferred by 14 and $11 \%$ of questioned, respectively. Soya and chickpea flour are preferred by 10 and $9 \%$ of interviewed, although this flour type has a lot of advantages: rich and balanced amino acid composition, gluten-free, high technological characteristics of ready products, high content of 
nutritive substances. The rather unessential percent is explained by the fact that pea flour contains phytic acid that prevents assimilation of iron, zinc and calcium, binding with them at penetrating the organism. Consumers are also afraid of a content of phytoestrogens and trypsin inhibitors, which agents are peas. And the fast development of genetics increases risks of buying flour of genomically modified varieties of soya and ckickpeas that influences consumption motivations as as a result the low $\%$ of consumption. Rice flour products are preferred by $7 \%$ of consumers (Fig. 2).

It has been established, that $20 \%$ of questioned persons feel a lack of bread with an increased content of protein and irreplaceable amino acids at the market that, in its turn, can be explained by the "instagram-fashion" of healthy nutrition together with physical loads for modeling the own body figure. $10 \ldots 15 \%$ of respondents want widening the assortment of bread with the increased content of macroelements, vitamins and microelements, 13 and $10 \%$ of interviewed feel a lack of bread of gluten-free flour and polyunsaturated fatty acids at the market. There is noted the high price of gluten-free bread and essential advantage of foreign producers of these products. Unessential percent (3-9\%) of respondents give preference to bread with a content of probiotics, dietary fiber, antioxidants and oligosaccharides (Fig. 3). The generalization of the studies gives reasons to state that important motivations of consumption preferences at developing bread for special dietary nutrition are the use of gluten-free flour with an increased content of protein and irreplaceable amino acids, fortified with vitamins, macro- and microelements. The first turn attention must be paid to the composition and safety of a product, its storage term, guaranteeing usual organoleptic parameters at low price. A consumer is guided by such criteria as food value, prophylactic properties, just these qualities must be improved at developing bread for dietary consumption.

\section{Conclusion}

1. It has been established, that $18 \%$ of respondents give preference to products with a decreased content of carbohydrates; $17 \%$ of respondents consume bread without gluten; $13 \%$ give preference to products, containing vitamins and nutrients; $10 \%$ consume iodi-containing bread; $7 \%$ and $6 \%$ of interviewed give preference to products with a content of soya and enterosorbents. $5 \%$ consumers' advantages were obtained by salt-free, protein-free products and ones with malts and dietary fiber. It has been established, that bread with carotene, sorbitol and lecithin is not widely demanded by consumers (by $3 \%$ ).

2. The conclusion was made that 19 and $17 \%$ of respondents give preference to corn and buckwheat flour, due to a higher content of healthy substances. Another important advantage became a fact that these flour types don't contain cellulose complexes, present in the composition of wheat and barley flour, preferred by 14 and $11 \%$ of interviewed, respectively. Soya and chickpea flour are preferred by 10 and $9 \%$ of interviewed. Rice flour is preferred by $7 \%$ of consumers and $5 \%$ of respondents prefer other flour types.

3. It has been experimentally established, that $20 \%$ among respondents feel a lack of bread with an increased content of protein and irreplaceable amino acids at the market. 15, 12 and $10 \%$ of respondents want widening the assortment of bread with the increased content of macroelements, vitamins and microelements, respectively. 13 and $10 \%$ of interviewed feel a lack at the market in such physiological-functional ingredients as polyunsaturated fatty acids and products of gluten-free flour. $8 \%$ of respondents want to see in the retail network products with a content of dietary fiber and antioxidants. $9 \%$ feel a lack of bread with a content of probiotics, $3 \%$ of oligosaccharides.

\section{References}

[1] Tsymbalysta, N. V., Davydenko, N. V. (2008). Stan faktychnoho kharchuvannia naselennia ta alimentarne obumovlena zakhvoriuvanist. Problemy kharchuvannia, 1-2, 32-35.

[2] Zhirkova, E. V., Martirosyan, V. V., Malkina, V. D., Reznikova, L. G. (2017). Primenenie inulinsoderzhashchego syr'ya v tehnologii muchnyh izdeliy. Mezhdunarodniy nauchno-obrazovatel'nyy Forum «Formirovanie otraslevoy innovatsionnoy sredy na osnove razvitiya professional'nyh soobshchestv i samoreguliruemyh organizatsiy APK, pishchevoy promyshlennosti i industrii pitaniya». Moscow: MGUTU, 158-160.

[3] Pro skhvalennia Kontseptsiyi Zahalnoderzhavnoi prohramy «Zdorovia 2020: ukrainskyi vymir». Rozporiadzhennia Kabinetu Ministriv Ukrainy vid 31.10.2011. Available at: https://zakon4.rada.gov.ua/laws/show/1164-2011-\%D1\%80 
[4] Pro skhvalennia proektu Kontseptsiyi Derzhavnoi naukovo-tekhnichnoi prohramy «Biofortyfikatsiya ta funktsionalni produkty na osnovi roslynnoi syrovyny na 2012-2016 roky». Postanova NAN Ukrainy vid 08.06.2011 No. 189. Available at: https://zakon.rada.gov.ua/rada/show/v0189550-11

[5] Syrokhman, I. V., Lozova, T. M. (2010). Yakist i bezpechnist zernoboroshnianykh produktiv. Kyiv: Tsentr navch. lyteratury, 184.

[6] Mardar, M. R., Zhyhunov, D. O., Ustenko, I. A. (2015). Designing of a new cereal product in accordance with consumer preferences. Technology Audit and Production Reserves, 2 (6 (22)), 67-72. doi: https://doi.org/10.15587/2312-8372.2015.41755

[7] Rusanova, S. V., Sablina, E. O., Kovalenko, S. N. (2009). Market research as basic constituent of quality function deployment. Upravlinnia, ekonomika ta zabezpechennia yakosti v farmatsiyi, 6 (8), 51-58.

[8] Mardar, M. R. (2013). Application of the method of quality functional deployment when developing a new extruded product. Meridian ingineresc, 2, 30-33.

[9] Roccia, P., Ribotta, P. D., Pérez, G. T., León, A. E. (2009). Influence of soy protein on rheological properties and water retention capacity of wheat gluten. LWT - Food Science and Technology, 42 (1), 358-362. doi: https://doi.org/10.1016/j.lwt.2008.03.002

[10] Hymowitz, T. (1970). On the domestication of the soybean. Economic Botany, 24 (4), 408-421. doi: https://doi.org/10.1007/ bf02860745

[11] Nilufer, D., Boyacioglu, D., Vodovotz, Y. (2008). Functionality of Soymilk Powder and Its Components in Fresh Soy Bread. Journal of Food Science, 73 (4), C275-C281. doi: https://doi.org/10.1111/j.1750-3841.2008.00727.x

[12] Makhynko, V., Drobot, V., Golikova, T. (2017). Effect of adding of plant protein isolates to the structural - mechanical properties of the wheat dough. Food and Environment Safety, XVI (2), 117-122.

[13] Makhynko, V., Sazhyna, A., Sokolovska, I. (2018). Products with high nutrient content: classification criteria. Pekar\&Kondyter, 2 (14), 38-40.

[14] Dorokhovych, V. V. (2010). Naukove obgruntuvannia tekhnolohiy boroshnianykh kondyterskykh vyrobiv spetsialnoho dietychnoho spozhyvannia. Kyiv, 307.

[15] Mardar, M. R., Kordzaia, N. R. (2013). Medical and biological estimation of bread made from a whole wheat grain with inclusion of root crops. Eastern-European Journal of Enterprise Technologies, 4 (10 (64)), 34-39. Available at: http://journals. uran.ua/eejet/article/view/16311/13834

[16] Do Carmo Barbosa Mendes de Vasconce, M., Bennett, R. N., Rosa, E. A. S., Ferreira-Cardoso, J. V. (2009). Industrial processing effects on chestnut fruits (Castanea sativaMill.). 2. Crude protein, free amino acids and phenolic phytochemicals. International Journal of Food Science \& Technology, 44 (12), 2613-2619. doi: https://doi.org/10.1111/j.1365-2621.2009.02092.x

[17] Akao, Y. (2010). Quality Function Deployment (QFD). Integrating customer requirements into product design. Portland, OR: Productivity Press, 239.

[18] Misuno, S., Akao, Y. (2004). QFD. The customer-driven approach to quality planning and deployment. Tokyo: Asian Productivity Organization, 341.

[19] Konopka, I., Tańska, M., Faron, A., Czaplicki, S. (2014). Release of free ferulic acid and changes in antioxidant properties during the wheat and rye bread making process. Food Science and Biotechnology, 23 (3), 831-840. doi: https://doi.org/10.1007/ s10068-014-0112-6

[20] Ivankiv, O. (2015). Analysis of Service Quality Perception Models on the Basis of Stakeholders Interests Harmonization. Ekonomichnyi chasopys Skhidnoievropeiskoho natsionalnoho universytetu im. Lesi Ukrainky, 1, 24-29. 